\title{
CAN LEGISLATION HELP TO CLOSE GENDER PAY GAPS?*
}

\begin{abstract}
The paper analyses the topic of unequal treatment of men and women and gender pay gaps. In the initial part, the author provides his views on the regulation of equal remuneration under the laws of the Czech Republic, as well as the causes for the gender pay gap and potential ways of closing it. In the subsequent chapter, comparison is drawn with the laws of the United Kingdom and Hungary which contain specific provisions that may have the potential to decrease gender pay gaps (gender pay gap reporting in the United Kingdom and obligation to adjust salaries following return from leave of absence in the Hungary). The author concludes that gender pay gap represents a complex phenomenon, but can be partly fought using legislative measures, and implementation of such measures seems necessary.
\end{abstract}

Słowa kluczowe: dyskryminacja, zróżnicowanie wynagrodzenia ze względu na płeć

Keywords: discrimination, gender pay gap

ASCJ: 3308, JEL: K 31

\section{Introduction}

One of the key paradigms of today's world is the principle of equal treatment of men and women and the prohibition of any discrimination on the basis of gender. No matter how many papers have already addressed the topic, we can still witness diverse forms of gender discrimination at the labour market. In this paper, I would like to particularly focus on one form - the problematic of unequal remuneration and monetization in the employment process taking the form of a so-called gender pay gap, and the potential ways of combating it.

* The Article reflects the legal status on 31 June 2018 and the conclusions of the author within the scope of projects UNCE/HUM/034 "Dependent work in 21. century: questions and challenges" and PROGRES Q03 "Private law and the challenges of today", Charles University, Faculty of Law. 
It is often argued that unequal remuneration has its deeps root in the current society, and there is little that the law can do to fight it. This paper reflects my view that this thesis is only partly correct. In the first part of the paper, I summarise the applicable legal regulation in the Czech Republic (with some remarks about the Polish regulation) and the main reasons for the existence of gender pay gaps. Second and third part of the paper result from my comparative study of the topic and present some examples where the lawmaker takes an active approach in this field. Conclusions are then summarized in the final part of the article.

\section{The issue and its possible legislative solutions}

In the Czech Republic, Section 110 of the local Labour Code (Act No. 262/2006 Coll., as amended) anchors the principle of equal wage for the same work, respectively for the work of equal value. In this context, the provision defines the criteria, which can be used by the employer to decide what is same work, respectively work of equal value. Therefore, wage disparities can be based on such criteria. The defined criteria include subjects like education, practical knowledge and skills, intricacy of work, work performance, work results and working conditions.

It could seem obvious that any wage policy of an employer must be based on an evaluation of objective criteria based in the nature of performed work, respectively on the predispositions to proper fulfillment of employee's duties, and on employee's results. Yet still, it is notoriously known that the wages of women are, in practice, lower than the wages of men. From the findings of Eurostat, it is clear that the difference between the income of men and women in the Czech Republic in the year of 2016, the so-called gender pay gap, amounted to $21.6 \%$. It is alarming that gender pay gap in the Czech Republic is the second broadest in the European Union, having been "surpassed" only by Estonia. The average value in the EU is $16.2 \%$ and most countries of CEE have achieved better results overall - in Poland, gender pay gap is much lower, in comparison with the Czech Republic, at only $7.7 \%$ of hourly men's pay. Romania, with $5.5 \%$, is at the pinnacle of the statistic.

There's a myriad of potential causes of gender pay gaps. Besides breaching the principle of equal wage for equal work, the cause can be (and very often is) the fact that men, rather than women, can be more frequently found in key and managerial positions (the horizontal segregation of the labor market), or that sectors that are associated with higher wages are generally dominated by men (vertical segregation of the labor market) (Jarrod 2016, p. 415). In cases like those, we cannot talk about discrimination, however, this phenomenon is not any less perplexing, considering that in the age group of 15-44 (from which most of the workforce pool comes from) we can see a predominance of women with completed tertiary education and secondary education ended with a final exam, whilst the largest group of men are, according to the statistics, secondary educated without an exam or a certificate (Czech Statistic Office 2017, p. 28). 
However, in a plethora of cases, men and women working in a comparable position receive a different wage. The causes might be diverse, from undervaluing women's work, through imposed disadvantages connected with maternity and parenthood, to inaction or unwillingness of employees in protesting their rights and to speak out against disparities (Špondrová 2016, p. 33).

With a bit of exaggeration, it would be possible to distinguish between the "intentional" disparity resulting directly from the employer's discriminatory intent and the "negligent", where the employer simply responds to the wage expectations of the candidates, which may be negatively affected by, for example, low pay from a previous employer or low self-confidence in the labor market, for example after returning from parental leave. It should be noted that in practice, it is not unusual for wages to be the result of bargaining, and the employer may tend to profit from such a low wage expectation. However, neither the wage expectations, nor the bargaining skills of the employee should even partially form the criteria to which the employer should look to when determining the wage (for a more rigorous argumentation to the irrelevance of discriminatory intention on the side of an employer, see for example the widely known verdict of the British Court of Appeals Fletcher v. Clay Cross Limited, case no. 19781 WLR 1429). The process of negotiating and forming the salary based on an agreement between the employer and the employee should not be the correct framework for salary determination. Instead, employers should work with predefined salary ranges which clearly reflect objective criteria outlined above. Some influence of negotiations may be accepted in the case where the employee occupies a unique position (although even in that case, the employer's offer should be a reflection on the value of the work in comparison with other, albeit different positions). However, if the employer wants to fill a position which is already existent and occupied by other employees, his bargaining power is limited by the wages received by those other employees and the duty to treat the recruited employee equally.

One could say that the biggest enemy of equal pay is the principle of the confidentiality of wages. We live in an environment where, at least in the private sector, it is a common idea of an employer that the employee's wage details represent confidential information that the employee is required to keep private (at least in relation to other employees). In employment contracts, we often read that breach of this duty constitutes a significant breach of duty for which employees are at risk of being disciplined; it is also reported in literature that maintaining the confidentiality of information about an individual's income has become a social custom (Havelková 2007, p. 28).

One consequence of such an environment is that there is only a very limited possibility of controlling the employer's wage policy. An employee who considers that his or her wage is lower than that of other workers carrying out work of equal value, has limited means as to gather information on which he or she could build up a reasonable claim against the employer, let alone to bear the burden of proof in a possible discriminatory dispute (let us recall that the institute of reversed burden of proof does not exempt employees from the obligation to claim and prove disadvantage - the verdict of the Highest court of the Czech Republic from the day 11 November 2009, case number: 
21 Cdo 246/2008). Not even inspections from the State Labour Inspection Office seem to be able to provide significant support here. After the Ministry of Labour and Social Affairs heard the Public Defender of Rights initiative in 2016 and increased the number of controls with focus on the area of equal pay (Šrajbrová 2016), we have, in the end, found out that only four cases of unequal pay for women have been proven and punished in one year (Šrajbrová 2017). It is not surprising that the work of the inspection in such cases is ungrateful: an experienced employer should not have a difficulty to find convincing reasons why a particular job or employee has a higher value, and an inspector coming from outside of the company may not have enough counterarguments or sufficient capacity, nor interests, to confront the employer (Válková 2016, p. 27). Employees are often discouraged from any cooperation with inspection authorities, as they cannot be guaranteed that their contribution will be processed anonymously, and many individuals may not find sufficient courage to stand up against the employer.

It could be argued that the fastest and easiest way to eliminate the gender pay gap would be to shift the paradigm completely and demand employers to be totally transparent about everyone's income (Canales 2018, p. 29). However, in my opinion, reaching such a situation is not real, at least in the foreseeable future. Setting a fair wage for a staff member is a relatively complex task, which should not only take account of the employee's job position but also of a number of other criteria relating to particular individuals, as is summarized above. It is not just a specifics of the private sector - on the contrary, it is obvious that such diversification is possible even in the governmental sphere, where salary ranges are defined by the law, but they can still be increased by individualized components as a personal surcharge, and other similar payments. It should be considered that many employees are not able to objectively compare their knowledge and abilities with the knowledge and abilities of their colleagues (or do not have enough information to do so). Absolute wage transparency could thus disturb the workplace atmosphere, lead to conflicts and, in the extreme, lead to a breakdown of employee relations at a number of workplaces.

Therefore, I believe that, in the context of the fight against gendered wages less radical measures need to be sought. Surprisingly, although the Czech Republic is among the countries with the largest gender gap, we cannot find any such particular measures, that could have the potential of limiting the gender pay gap, in our legislation and politics. A comparative analysis of employment laws may therefore be appropriate to look at possible inspiration. In this context, given the limited scope of this paper, I would like to refer to two specific legal measures from Great Britain and Hungary.

\section{Great Britain - gender pay gap reporting}

On 6 April 2017, an amendment to the Equality Act 2010 became effective in Great Britain. The essence of the novelty is the introduction of an obligation for employers employing at least 250 employees to publish a report containing data on average and 
median values of hourly wages of male and female employees. Employers are further required to divide the employees into four quarters according to the hourly wage and to disclose the share of men and women in each quarter. The information must be made available in a sufficiently visible place on the employer's website and it must be published on the website of the British Government as well ("Gender Pay Gap Service").

Legislation implies a clear obligation to carry out the reporting but, on the other hand, the regulation does not expressly envisage any follow-up actions (e.g. controls of public authorities or possible claims of employees following the findings of a broad gender pay gap). This legislation may thus appear to be toothless. It must be, however, noted that the novelty has attracted great public interest. Shortly after the deadline for disclosure of data for 2017, British media filled with articles highlighting the case of the company with the highest gender pay gap (Butler 2018), the BBC media service published an interactive search engine in which everyone can search through data from all companies (What Is... 2018) and companies with high gender pay gap have been subjected to considerable criticism. The BBC itself was also heavily criticized because of its unequal policy, and was publicly called out by a group of 170 female workers (Kentish 2018). It can be hypothesized that such a media attention might help employees who are discriminated against to find the motivation to deal with the situation and to use the situation to put pressure on their employer.

The question is to what extent the introduction of similar obligations would have similar effects in the Czech Republic or other Eastern European countries. It is undisputed that the sensitivity of public to discrimination in the UK is much higher than in Eastern Europe. While only units of discriminatory disputes are opened every year, the United Kingdom reports almost 30,000 cases annually (EHRC 2017). The question is whether the actual publication of the overall societal data and the public debate about them will be a sufficient impetus for change. It will be interesting to see if the data reported in the second, third and subsequent years of the new adjustment will testify to the reduction of the gender pay gap or whether the data will remain the same. In any case, however, I believe that this is a step in the right direction, which should be followed by other countries where gender pay gap is a social problem, with the Czech Republic in the first place.

It is only possible to ask whether it is appropriate for the limit of the reporting obligation to be set at employers with at least 250 employees. It is obvious that it is not meaningful for a given obligation to burden small entrepreneurs who often do not have more employees in the same or comparable position. However, unequal treatment can also occur for employers with fewer employees and, as a result, it may make sense to reduce the threshold.

\section{Hungary - wage adjustment during parental leave}

Section 59 of the Hungarian Labor Code (Act I of 2012) states that upon the expiry of parental leave, the employer must propose a salary adjustment taking into account the average annual salary increment that has occurred in the meantime for employees in the 
same position. If such employees are not existent, the average annual wage increment of all employees at the employer shall be applied.

The Hungarian legal order, like in the Czech Republic, establishes the possibility for the employee to take up parental leave until the third birthday of the child ( $\$ 128$ of the Hungarian Labor Code). This legal solution fits in with the traditional concepts of childcare, but in practice it weakens the position of an employee who returns to the labor market after several years of interruption, whilst creating a specific category of precarious "replacement" employees covering for these workers, who cannot reach work contract for an indefinite period as their contract term is limited by the date when the absent employee returns to work.

Especially in times of economic growth, employees returning from a leave of absence can be disadvantaged in another specific way: under Czech law, they have the right to a wage that they have agreed on or has been determined by the employers many years ago, before commencing a parental leave. The wages of other employees have often increased during their absence. In that context, employees returning from parental leave are not always in a sufficiently strong bargaining position to convince the employer to raise their salary or to find a different job right away. It may therefore seem fair that the Hungarian law makes it necessary for the employer to increase the wages accordingly and thus close the difference.

Against the proposal above, it could be argued that the reason for wage increases is not always just inflation and increasing the level of market prices, but also individual employee results, acquired seniority, new experience and other similar factors. We can imagine two employees performing the same job for employers. While one is on parental leave, the other one works to improve their knowledge and performance, and once he or she succeeds, the employer will raise their wage as a matter of appreciation of such personal development. If the employer subsequently had the obligation to equally increase the salary of the employee who returns from parental leave but their knowledge and performance remained at the original level, such an arrangement would be unfair to the employee who "worked" for their wage increase.

With regards to salary changes following inflation, the law does not stipulate any obligations for employers in this respect. (In the Czech Republic, regular salary increases at a level close to the inflation rate are often contained in collective bargaining agreements. The share of unionised companies with a collective bargaining agreement, however, keeps decreasing). On the other hand, compensating general price increases represents an important part of reasons of salary increases, which may be also a component of other frequently declared reasons (e.g. following market practices and increases of salaries at the market). Given the absence of a general obligation to raise wages, it would not be sustainable for this duty to be generally enshrined for employees returning from a parental leave. Notwithstanding that, the issue could be addressed with a rule stating that if the employer, at the time of the absence of an employee, increased the wages of the employees doing the same job (including the "replacement" for an absent employee), it would be his duty to increase the wage of the absent employee by at least the amount of inflation during their absence period; if there was no employee doing the same job, 
the wages of employees of the same department or of all employees at the employer should be taken into account.

\section{Conclusion}

Gender pay gap seems to be a complex phenomenon. It is partly based on reasons that are outside the sphere of law (e.g. horizontal and vertical segmentation of the labour market) or that can be influenced by the lawmakers in a limited manner only (e.g. general lack of interest to litigate). However, certain part of the difference is apparently due to discriminatory practices. Such discriminatory practices will not disappear unless a significant proportion of employees makes a decision to challenge them, and unless courts adopt an approach where it will be economically inefficient for employers to pursue unequal remuneration practices (e.g. due to amounts of compensation awarded to victims of discrimination). Yet still, the law is capable of offering mechanisms that can be used as methods to combat unequal remuneration.

No matter how much has been written about the issue of gender discrimination and even unequal pay, this increased attention does not lead to a significant improvement in the situation. As a result, I consider it important to pursue this topic even further and to consider legislative measures including those mentioned above. It is rather concerning to see that despite of the alarming gender pay gap figures, the Czech state - as well as other EU countries - has not taken any measures to close the gap, and as a result, it bears a substantial part of the blame. As the topic is not country specific, debate on an international level can be helpful, and it could even lead to the conclusion that the topic deserves a regulation on the EU level.

\section{References}

Butler S. (2018) The UK Companies Reporting the Biggest Gender Pay Gaps, “The Guardian” 5 April, https://www.theguardian.com/society/2018/apr/05/the-uk-companies-reportingthe-biggest-gender-pay-gaps (access: 14 March 2019).

Canales B. (2018) Closing the Federal Gender Pay Gap through Wage Transparency, "Houston Law Review", vol. 55, issue 4, p. 969-997.

Czech Statistic Office (2017) Zaostřeno na ženy a muže Prague, s. 28, https://www.czso.cz/documents/10180/45709978/30000217.pdf/92da801e-56d6-4d45-8cef-67497ed59949?version=1.1 (access: 28 July 2018).

Equality and Human Rights Commission (EHRC) (2017) One Year on: An Update on Discrimination Claims in the Employment Tribunal.

Havelková B. (2007) Rovnost v odměňování žen a mužư, Praha.

Jarrod T. (2016) Closing the Gender Pay Gap in the European Union: The Equal Pay Guarantee across the Member-States, "North Dacota Law Review", vol. 92, issue 2, p. 415-472. 
Kentish B. (2018) BBC Gender Pay Gap: 170 Female Employees Demand Apology over Salary Differences and 'Culture of Discrimination', "Independent” 30 January, https://www.independent. co.uk/news/uk/politics/bbc-gender-pay-gap-employees-apology-bbc-women-nuj-tonyhall-select-committee-a8184306.html (access: 14 March 2019).

Špondrová P. (2016) Almanach from the International Conference on Wage Unequality, Brno.

Šrajbrová M. (2016) Inspekce práce se zaměří na rovné odměňování žen a mužu. Kontroly na jaře zamírí do vybraných firem, "Hospodářské noviny" 17 February, https://domaci.ihned. cz/c1-65167570-inspekce-prace-se-zameri-na-rovne-odmenovani-zen-a-muzu-kontrolyna-jare-zamiri-do-vybranych-firem (access: 28 May 2018).

Šrajbrová M. (2017) Ženy dostávaly za stejnou práci nižší plat, odhalila inspekce. A to i u policie, "Právní rádce", č. 4, https://pravniradce.ihned.cz/c1-65683220-zeny-dostavaly-za-stejnou-praci-nizsi-plat-odhalila-inspekce-a-to-i-u-policie (access: 28 May 2018).

Válková J. (2016) Poziční dokument k nerovnému odměňování žen a mužů v České republice, Brno, http://www.gendernora.cz/download/62.pdf (access: 14 March 2019).

What Is the Gender Pay Gap at Your Company? (2018) "BBC" 5 April 2018, http://www.bbc. co.uk/news/business-43632763 (access: 14 March 2019).

http://www.ilo.org/dyn/travail/docs/2557/Labour\%20Code.pdf [Hungarian Labour Code] (access: 14 March 2019).

https://gender-pay-gap.service.gov.uk [“Gender Pay Gap Service”] (access: 14 March 2019). https://www.legislation.gov.uk/ukdsi/2017/9780111152010 [an amendment to the Equality Act 2010] (access: 14 March 2019). 